Jurnal Psikologi Teori dan Terapan

2016, Vol.7, No. 1, 50-61, ISSN: 2087-1708

\title{
Studi Kasus Penerimaan Seorang Ayah Terhadap Anak Autis
}

\author{
Ade Surya Febrianto, dan Ira Darmawanti \\ Program Studi Psikologi Universitas Negeri Surabaya
}

\begin{abstract}
The purpose of this study was to explore the process of fathers' acceptance to their children with autism. This study used a qualitative approach. Three participants who are fathers of children with autism were involved in this study. Data were collected using semi-structured interviews and analyzed using thematic analysis. This study reveals three themes, namely participants' responses on their autistic children; the psychological experiences of having children with autism; and making efforts to accept their autistic children. In general, the result of this study shows that the participants have different experiences in raising their autistic children. This study also found various forms and aspects of acceptance that are experienced by participants
\end{abstract}

Keywords: Acceptance, father, children with autism

\begin{abstract}
Abstrak: Penelitian ini bertujuan untuk melihat bagaimana proses penerimaan seorang ayah terhadap anaknya yang menyandang autisme. Penelitian ini menggunakan pendekatan kualitatif. Karateristik partisipan penelitian meliputi ayah yang memiliki anak dengan diagnosis autisme. Jumlah partisipan dalam penelitian ini sebanyak 3 orang. Teknik pengumpulan data dengan wawancara semi terstruktur, dan analisis data dilakukan dengan menggunakan analisis tematik. Penelitian ini mengungkapkan 3 (tiga) tema yaitu tanggapan terhadap autism anaknya; pengalaman psikologis memiliki anak autis; dan upaya yang dilakukan untuk mencapai penerimaan terhadap anaknya. Hasil penelitian ini menunjukan bahwa secara umum ketiga partisipan memiliki pengalaman berbeda dalam merawat anak mereka yang didiagnosis autisme. Penelitian ini juga menemukan beberapa bentuk penerimaan yang dialami partisipan serta aspek-aspek penerimaan partisipan terhadap anaknya yang autis..
\end{abstract}

Kata Kunci: Penerimaan, ayah, anak dengan autisme

Kehidupan berkeluarga kehadiran anak merupakan hal yang istimewa. Kelahiran anak dipandang bernilai karena membuat pasangan suami istri lebih dewasa dan dihargai oleh masyarakat sekitar. Anak merupakan ekspresi dan kontinuitas orang tua dalam hal karakteristik diri dan nama keluarga, anak juga merupakan pemberian dan titipan Tuhan yang harus dirawat sebaik mungkin.
Keadaan akan menjadi berubah ketika anak yang lahir, berbeda dengan anak lainnya, yakni anak yang memerlukan perhatian atau kebutuhan khusus, termasuk dalam hal ini memiliki keturunan anak berkebutuhan khusus (ABK). Menurut Delphie (2004) anak berkebutuhan khusus merupakan istilah lain untuk menggantikan kata "Anak Luar Biasa" (yang menandakan kelainan khusus).

Korespondensi tentang artikel ini dapat dialamatkan kepada Ade Surya Febrianto melalui e-mail: adesurya333@gmail.com 
Menurut Mangunsong (1998) reaksi yang muncul pada orang tua ketika anaknya dikatakan memiliki permasalahan pada kondisi fisik maupun kesehatan adalah tidak percaya, terjadi goncangan batin, terkejut dan tidak mempercayai kenyataan yang menimpa anak mereka. Bukan hal yang mudah bagi orang tua untuk percaya bahwa anaknya dikatakan bermasalah, apalagi anaknya dikatakan menyandang autisme. Beberapa orang tua ada yang memiliki dorongan untuk melarikan diri dari masalahnya, berpurapura bila anak mereka tidak memiliki kekurangan. Mereka merasa tidak nyaman dengan perasaan berpura-pura itu sehingga mereka mengambil tindakan sebaliknya, mereka menjadi terlalu cemas dan terlalu berlebihan dalam menjaga anak.

Beberapa orang tua ada yang memiliki dorongan untuk melarikan diri dari masalahnya, berpura-pura bila anak mereka tidak memiliki kekurangan. Mereka takut anaknya hilang dari pandangannya, tidak membiarkannya berinteraksi dengan orang lain, dan bahkan mereka cenderung melarang anaknya untuk melakukan sesuatu hal sendiri tanpa bantuan mereka. (Greenspan, 2006). Saat orang tua mengetahui bahwa anaknya memiliki permasalahan dalam kesehatannya terlebih lagi telah didiagnosa autisme maka timbul perasaan terpukul, putus asa, kesal, menyalahkan diri sendiri, merasa dirinya tidak berguna, melakukan penawaran-penawaran mengapa hal ini terjadi pada keluarganya, timbul dua perasaan bertentangan antara menerima dan menolak, tidak percaya diri, mengalami kebingungan untuk mengasuh anak (Indra, 2011).

Ayah sebagai kepala keluarga berperan sebagai sumber penghasilan dan pembentukan karakter pada keluarga. Selain itu ayah juga merupakan pelindung anggota keluarganya sehingga terciptalah suasana nyaman dan aman bagi pasangan maupun anak-anaknya. Ayah memiliki peranan tersendiri dalam membesarkan anak autis. Ayah akan cenderung mengajarkan banyak hal kepada anakanaknya tentang hidup dengan cara mereka masing-masing. Peran ayah juga dibutuhkan dalam perkembangan seorang anak, tidak selalu secara ekonomi saja. (Meadous,2000). Ayah memiliki kontribusi yang sama terhadap perkembangan anak dengan gangguan autis, terutama dalam bidang bahasa dan bermain simbolis (Michelle \& Elizabeth, 2011).

Penerimaan ayah terhadap anak yang memiliki gangguan autisme memerlukan pengetahuan yang luas tentang autisme itu sendiri, sehingga ayah akan memahami arti dari autisme yang sebenarnya. Pada umumnya ayah mengalami fase demi fase penerimaan terhadap anaknya yang berkebutuhan khusus meliputi; fase denial, fase anger, fase bargaining, fase depression hingga pada akhirnya mengalami fase acceptance (Rose, 2008).

\section{Metode}

Penelitian ini, penulis mencoba untuk menggali lebih dalam tentang proses penerimaan seorang ayah yang memiliki anak autis peneliti menggunakan pendekatan kualitatif. Penelitian kualitatif yang digunakan adalah studi kasus, karena dalam penelitian studi kasus mencoba untuk melihat suatu kasus dari beberapa sumber data yang dapat mengungkap kasus tersebut. Penelitian studi kasus adalah suatu model yang menekankan pada pengembangan dari suatu sistem yang terbatas pada satu atau beberapa kasus secara mendetail yang melibatkan beragam sumber informasi dengan melakukan panggilan data secara mendalam (Herdiansyah, 2010).

Pengambilan partisipan dalam penelitian ini menggunakan teknik purposive sampling dengan karakteristik partisipan adalah seorang ayah yang memilik anak autis dan bersedia menjadi partisipan dalam penelitian ini, dengan lokasi penelitian di kota Sidoarjo. Peneliti 
juga menggunakan teknik key person, dimana peneliti mendapatkan rekomendasi partisipan dari seorang terapis disalah satu tempat terapi yanga da di kota Sidoarjo.

Tabel 1. Karakteristik Partisipan

\begin{tabular}{cccll}
\hline No & Nama & Usia & Pendidikan & Pekerjaan \\
\hline 1 & Alex & 37 & STM & Tidak bekerja \\
2 & Seto & 49 & SD & Pedagang \\
3 & Tono & 40 & S2 & PNS \\
\hline
\end{tabular}

Teknik pengumpulan data dalam penelitian ini menggunakan wawancara semi terstruktur dan observasi semi partisipasn. Instrumen wawancara yang digunakan adalah pedoman wawancara dan alat perekam. Tujuan peneliti menggunakan bentuk wawancara semi terstruktur adalah untuk kedalaman pada menggali informasi dari subjek maupun informan, karena bentuk wawancara semi terstruktur ini memungkinkan peneliti untuk mengajukan pertanyaan-pertanyaan yang lebih spesifik dan lebih fleksibel guna menjaga kenyamanan subjek tanpa mengurangi nilai informasi.

Teknik analisis data dalam penelitian ini adalah analisis tematik. Penggunaan analisis tematik memungkinkan peneliti menemukan "pola" yang pihak lain tidak melihatnya secara jelas. Pola atau tema tersebut seolah secara acak dalam tumpukan informasi yang tersedia. Setelah itu dapat ditemukan pola ("seing"), akan menghasilkan atau meng'encode' pola tersebut ("seing as") dengan menggunakan label, definisi atau deskripsi (Boyatzis 1998, dalam Poerwandari, 2001).

Uji keabsahan data penelitian ini menggunakan triangulasi. Peneliti menggabungkan triangulasi sumber dan triangulasi teknik atau metode. Peneliti menggunakan teknik pengumpulan data observasi dan wawancara sebagai triangulasi teknik serta melakukan wawancara dengan ayah dan significant other sebagai triangulasi sumber.

Significant other dalam penelitian ini adalah istri dari setiap partisipan yang mengetahui pengalaman interaksi serta usaha para partisipan dalam menerima anak mereka yang memiliki kebutuhan khusus autisme.

\section{Hasil}

Penelitian ini bertujuan untu mengungkap proses seorang ayah menerima anaknya dengan gangguan autisme. Peneliti berhasil mengungkap 3 tema, yaitu (1) Respon terhadap autism anak autis; (2) pengalaman psikologis memiliki anak autistik; dan (3) upaya penerimaan terhadap anaknya yang autis.

\section{Respon terhadap autism anaknya}

Pemikiran awal yang muncul adalah menanyakan pada diri sendiri mengapa hal ini bisa terjadi pada dirinya. Hal tersebut timbul dalam pemikiran Alex.

\section{" Pemikiran pertama yang yang muncul itu kenapa hal ini bisa terjadi pada keluarga saya ?" (Alex)}

Namun selanjutnya Alex mengungkapkan bahwa apa yang sedang ia alami ini merupakan suatu cobaan dari Tuhan dan ia meyakinkan dirinya bawa ia dapat mengahadapi pencobaan tersebut.

\footnotetext{
" menganggap semua ini hanya cobaan dari Allah yang pasti bisa saya hadapi ". (Alex)
}

Sikap ini juga menjadi pilihan Tono. Ia menjelaskan bahwa anaknya merupakan anugerah istimewa yang diberikan Tuhan kepada dirinya. Tono percaya bahwa Tuhan mengerti bila dirinya mampu untuk merawat dan memberikan kasih sayang kepada NIKO anaknya.

\footnotetext{
"bahwa saya dianugerahi NIKO yang diberikan kondisi seperti ini, berarti Tuhan tahu bahwa saya ini mampu untuk merawat dan mengasihi NIKO mas." (Tono)
}

Hal yang sama juga menjadi pendirian Seto. Ia memandang apa yang dialami 
memang merupakan suatu cobaan dari Tuhan bagi keluarganya. Berbeda dengan istrinya yang merasa terpukul, Seto berusaha tetap kuat.

\footnotetext{
"apa yang saya alami ini adalah suatu cobaan dari Allah bagi saya dan istri saya" (Seto)

"sudah saya ceritakan kalau yang merasa terpukul banget itu istri saya.. lah saya itu kalau gak tegar mas,. yang nyemangati istri saya siapa ?'(Seto)
}

\section{Pengalaman psikologis memiliki anak autis}

Alex merasa bahwa dirinya telah diremehkan oleh keluarga besarnya karena anaknya didiagnosis autism.

\footnotetext{
"kalau kakak-kakak saya meremehkan saya,.. seoalah-olah saya tidak becus mengurus rumah tangga saya" (Alex)
}

Hal tersebut juga dijelaskan dalam pernyataan istri Alex, bahwa suaminya Alex sempat merasa marah ketika mendapat hinaan dari keluarganya, dan bahkan membuat Alex merasa putus asa dengan kondisi tersebut.

"Bapak itu emosi saat keluarga itu,.. apa ya.. seperti menghina dia gitu lho mas.. ya sempat dia seperti putus asa gitu mas" (Siti)

Mendapat tanggapan negatif dari keluarga Alex merasa marah.

"Saya marah mas, sampai saya tidak mau lagi mengajak istri dan anak saya bertamu kerumah kakak saya"(Alex)

Perasaan putus asa sempat datang pada partisipan, Alex dan Seto mengatakan bahwa dirinya merasakan putus asa saat mencoba untuk mengatasi masalah yang dihadapi. Alex merasa putus asa karena sikap yang kurang menyenangkan dari keluarga. Diremehkan dari kakaknya merupakan pemicu awal perasaan putus asa yang dirasakan Alex.

\begin{abstract}
" Jujur pada saat itu saya sempat putus asa, anak saya kok seperti ini.. dan ditambah lagi kakak-kakak saya merendahkan saya, seolah-olah saya ini tidak sanggup menjadi kepala rumah tangga" (Alex)
\end{abstract}

Bila Alex merasa putus asa karena diremehkan, berbeda lagi dengan apa yang dialami oleh Seto. Ia mengatakan saat awal mulai merasa putus asa saat dirinya lelah berusaha untuk menyembuhkan anak. Berkali-kali mencoba penanganan kesanakesini, dari mulai pengobtan yang rasional hingga yang irasional.

"4 tahun saya dan istri sudah berusaha kesana-kesini, tetapi hasilnya masih sama saja.. sampai capek kita mas, sudah bingung bagaimana menangani SELA" (Seto)

Berbeda dengan kedua partisipan lain, Tono masih merasa beruntung. Ia masih bersyukur karena kondisi yang dihadapi anaknya tidaklah terlalu buruk
"Puji Tuhan menurut psikolog di CHB itu kalau autis Asperger itu tergolong anak autis yang cerdas,.. tidak seperti autis yang mengalami hambatan serius seperti verbalnya yang benar-benar tidak bisa bicara" (Tono, h. 33)

\section{Upaya penerimaan terhadap anak}

Tono menjelaskan bahwa ayah juga memiliki peran yang cukup banyak dalam merawat anak. Tono berpikir bahwa sosok seorang ayah sebagai pemberi hak kepada anak, salah satunya adalah hak untuk mendapatkan kasih sayang dari ayah.

"dia tanya apa ya saya jelaskan, tidak selalu hal seperti itu adalah peran ibu.. itu saja sih mas yang bisa saya lakukan.. karena itu cara saya untuk menyayangi dia, bagaimana dia bisa merasakan kasih sayang dari ayahnya". (Tono, h. 43)

Alex juga mengungkapkan perasaan bahagianya dengan hadirnya anak dalam 
hidup rumah tangganya. Apapun kondisinya Alex tetap menyayangi anaknya, Alex tidak peduli dengan pandangan negatif dari kakak-kakaknya. Alex juga menjelaskan bahwa anaknya merupakan semangat bagi dirinya disaat dirinya pernah koma dirumah sakit

" ini anak saya, dan apapun itu saya akan tetap menyayanginya, tidak peduli bagaimana kondisinya dan saya tidak peduli bila diremehkan oleh kakak saya" (Alex, h. 05)

"dia anugerahku mas,. semangat bagi saya saat saya sedang kritis di rumah sakit ". (Alex, h. 12)

Sama halnya dengan Seto yang menganggap bahwa anaknya merupakan anak yang istimewa bagi dirinya. Kebahagiaan Seto dituangkan dalam harap sederhana yaitu memeberi nama SELA pada anaknya dengan harapan bahwa anaknya menjadi anak yang dapat berbakti bagi dirinya dan istrinya.

"kalau SELA sendiri bagi saya anak istimewa, saya juga memberi nama SELA itu dengan harapan bahwa anak saya ini kelak menjadi anak yang sholeha, hidupnya kelak menjadi orang lurus hidupnya dalam agama dan bangsa.. bisa berbakti pada orang tuanya" (Seto, h. 26)

\section{Pembahasan}

Berkeluarga merupakan anugerah tersendiri dalam sebuah kehidupan individu. Orang tua mengharapkan anaknya tumbuh menjadi anak yang cerdas, dan berhasil dalam pendidikannya, namun keadaan akan berubah bila orang tua memiliki anak dengan kebutuhan khusus (ABK). Reaksi yang muncul pertama kali pada orang tua ketika anaknya memiliki permasalahan pada kondisi fisik maupun kesehatan adalah tidak percaya, adanya goncangan batin dalam dirinya, dan tidak mempercayai kenyataan yang menimpa anak mereka (Mangungsong, 1998). Perasaan tak percaya bahwa anaknya mengalami autis kadang-kadang menyebabkan orang tua mencari dokter lain untuk menyangkal diagnosis dokter sebelumnya, bahkan sampai beberapa kali berganti dokter (Safira, 2005).

Ayah sebagai kepala keluarga berperan sebagai sumber penghasilan dan pembentukan karakter pada keluarga. Selain itu ayah juga merupakan pelindung anggota keluarganya sehingga terciptalah suasana nyaman dan aman bagi pasangan maupun anak-anaknya. Ayah memiliki peranan tersendiri dalam membesarkan anak autis. Ayah akan cenderung mengajarkan banyak hal kepada anakanaknya tentang hidup dengan cara mereka masing-masing. Peran ayah juga dibutuhkan dalam perkembangan seorang anak, tidak selalu secara ekonomi saja. (Meadous,2000). Ayah memiliki kontribusi yang sama terhadap perkembangan anak dengan gangguan autis, terutama dalam bidang bahasa dan bermain simbolis (Michelle \& Elizabeth, 2011).

Penelitian menemukan 4 tema besar, dari tema tersebut dapat dilihat proses penerimaan yang dialami partisipan. Tema Tanggapan awal terkait autisme pada anak menggambarkan bagaimana partisipan menyikapi suatu respon positif dan negatif dari orang disekitarnya. Partisipan juga mengalami suatu pengingkaran dalam dirinya, dimana partisipan berpikir mengapa hal buruk itu menimpa keluarganya. Adanya suatu pengingkaran merupakan suatu tahap Denial. Respon awal seseorang ketika mengalami kondisi yang tidak diinginkan akan mengingkari ketidak nyamanan kondisi tersebut terjadi dalam hidupnya (Ross, 2008). Hasil interaksi dengan orang disekitar yang berkaitan dengan autisme pada anak membuat partisipan memunculkan respon marah, mereka merasakan kemarahakan bukan karena keautisan yang terjadi pada anak dan keterbatasannya. 
Ketiga partisipan mengalami kemarahan akibat respon negatif dari orang di sekelilingnya. Kemarahan tersebut juga mengakibatkan salah satu partisipan menyalahkan istri sebagai penyebab keautisan pada anak. Ada juga partisipan yang sangat marah ketiga mendapat penolakan dari keluarga besar atas dirinya, yang dianggap tidak kompeten dalam menjadi kepala rumah tangga sehingga anak mengalami autisme. Apa yang dialami partisipan tersebut merupakan suatu tahap anger atau kemarahan, Ross (2008) mengatakan seseorang berada pada tahap kemarahaan ketika tidak dapat mengatasi pengingkaran kondisi buruk yang dialami. Adanya pengingkaran dari sekelilingnya membuat partisipan marah, namun kemarahan yang ditunjukan oleh partisipan adalah kemarahan bukan karena keautisan anak melainkan kepada respon negatif dari lingkungan sekitarnya.

Tema pengalaman psikologis memiliki anak autis menggambarkan bahwa partisipan mengalami berbagai kondisi dalam mengurus anak, secara psikologis partisipan merasakan stress dalam menangani anak sehari-hari. Partisipan merasa kebingungan akan bahasa non verbal yang muncul pada anak mereka, yang terkadang membuat partisipan merasa kesusahan dalam menenangkan anak saat mengalami tantrum. Penelitian lain yang senada dengan kondisi tersebut adalah penelitian Rachmayanti \& Zulkaida (2007) yang menyatakan bahwa orangtua Anak Berkebutuhan Khusus. Sempat mengalami stress, bingung dan khawatir dalam menghadapi keadaan anak. Hal tersebut dikarenakan mereka yang menangani dan mengurus semua keperluan anak seharihari. Partisipan pertama (Alex) yang sering mengalami kebingungan dalam menangani anak, hal ini karena Alex memiliki peran sebagai orangtua yang mengurusi semua keperluan anak sehari-hari kecuali dalam hal memasak. Memahami kondisi anak merupakan salah satu bentuk dari penerimaan, Puspita (dalam Rachmayanti \& Anita, 2007) mengatakan salah satu bentuk penerimaan adalah memahami kebiasaan-kebiasaan anak.

Partisipan juga sempat mengalami perasaan putus asa dalam menangani anak. Perasaan putus asa partisipan muncul akibat mereka merasa sia-sia penanganan anak selama ini yang sudah dialakukan sebelum menempatkan anak pada rumah terapi khusus. Kondisi tersebut menunjukan partisipan berada pada tahap Depression Ross (2008) yang menjelaskan seseorang sudah melewati tahap pengingkaran, kemarahan dan tahap tawarmenawar. Seseorang akan merasa memiliki rasa kehilangan yang sangat besar (dalam hal ini kehilangan keinginannya untuk mengalami kondisi yang sesuai dengan keinginannya).

Penanganan yang baik dan tepat juga merupakan salah satu cara bagaimana partisipan mengatasi kondisi buruk yang dialami. Tema strategi penanganan anak menggambarkan bagaimana partisipan mengambil tindakan-tindakan dalam mengatasi permasalahan memiliki anak autis. Partisipan menempatkan anak ditempat pusat terapi dilakukan dengan harapan bahwa anak mereka dapat sembuh. Hal ini juga seperti yang dikatakan Anita (2007) mengupayakan penanganan alternatif sesuai dengan kebutuhan anak merupakan sebuah bentuk dimana orangtua sudah dapat menerima anaknya.

Alex mulai berusaha bangkit ketika pada tahap Depression dengan memunculkan perasaan positif dalam dirinya. Alex menganggap apa yang dirinya alami ini merupakan hanya cobaan dari Allah dimana dirinya mampu untuk mengatasi semuanya ini. Alex menganggap bila dirinya lebih memperkuat imannya makan dirinya pasti mampu mengatasi masalah tersebut. Kondisi tersebut merupakan tahap Bargaining atau tahap tawar-menawar Ross (2008) Tahap ini merupakan tahap ketika seseorang melakukan tawar-menawar dengan kondisi 
yang tidak ia inginkan. Seto yang mengalami Bargaining terlebih dahulu dari tahap Depression. Perasaan depresi yang dialami Seto muncul ketika dirinya sudah merasa bertahun-tahun mengatasi autisme pada anak melalui pengobatan alternatif adalah sia-sia. Seto berada pada tahap Bargaining, ketika melihat depresi yang dialami oleh istri, Seto beranggapan bila dirinya juga mengalami depresi seperti istrinya maka siapa yang akan berusaha mencari jalan keluar dari masalah tersebut.

Partisipan juga mengalami kekhawatiran anak masa depan anak dan keterbatasaan anak mengungkapkan bahwa partisipan mengalami kecemasan akan apa yang terjadi pada anak dimasa ini maupun dimasa depan anak. Partisipan mengakui ketidak berdayaan anaknya dalam hidup secara sosial dimasyarakat umum. Rachmayanti \& Anita (2007) mengatakan bahwa salah satu bentuk penerimaan yang terjadi pada orangtua adalah menyadari akan apa yang bisa dilakukan anak dan apa yang belum bisa dilakukan anak.

Tema upaya yang dilakukan dan evaluasi menjelaskan partisipan melakukan berbagai upaya dalam mengatasi autisme pada anak. Partisipan melakukan bermacam-macam upaya dalam mengatasi anak. mulai dari peran pengasuhan anak sehari-hari hingga bagaimana partisipan mencari bantuan kepada tenaga medis dan meminta bantuan kepada non medis. Puspita (dalam Rachmayanti \& Anita, 2007) mengatakan bentuk penerimaan orangtua juga dapat dilihat dari bagaimana orangtua dapat mengupayakan alternatif penanganan sesuai kebutuhan anak. Partisipan juga mengupayakan pengobatan anak melalui suatu kepercayaan yang terjadi pada masyarakat diIndonesia. Orientasi pemikiran partisipan masih terpengaruh oleh kepercayaan yang ada dimasayarakat Indonesia, dan partisipan masih menganggap bahwa autisme pada anak adalah sebuah penyakit.

Tema penerimaan terhadap anak mengungkapkan bagaimana ketiga partisipan mulai menerima kondisi anak, penerimaan yang terjadi terlihat bagaimana ketiga partisipan memiliki harapan untuk masa depan anak. Ketiga partisipan tetap mengharapkan kesembuhan untuk anak, dan langkah menempatkan anak ke rumah terapi dengan harapan anak dapat hidup secara mandiri. Partisipan juga menghargai anak sebagai individu yang berhak mendapat kasih sayang dari ayah. Perasaan bahagian menunjukan bahwa partisipan dengan ikhlas menerima anaknya meskipun dalam kondisi autisme, cara partisipan menghargai anak mereka seperti apa yang dikatakan Ningrum (dalam Laurent, 2011), orang tua dapat menunjukan dengan menempatkan anaknya pada posisi penting dalam keluarga dan mengembangkan hubungan emosional yang hangat dengan salah satunya menghargai anak sebagai individu dengan segenap perasaan.

Adanya kepercayaan yang besar terhadap Tuhan membuat partisipan dapat bersikap dengan bijak dalam menanggapi masalah mereka. Partisipan berpikir bahwa segala sesuatu yang mereka alami ini dapat diatasi dengan bantuan Tuhan. Mereka mencurahkan perasaan kesedihan mereka memiliki anak autis dalam doa sehari-hari mereka. Mereka berharap adanya timbalbalik dari upaya doa, sehingga Tuhan dapat mampu menyembuhkan anak mereka. Hal tawar-menawar ini merupakan membutikan bahwa ketiga partisipan berada pada tahap penerimaan Bargaining. Ross (2008) seseorang sudah mulai tawar menawar dengan kondisi yang tidak diinginkan merupakan tahap Bargaining. Tahap dimana orangtua berusaha menghibur diri dengan penyataan seperti "mungkin kalau kami berpasrah pada Tuhan, keadaan akan membaik dengan sendirinya".

Penerimaan ayah terhadap anak yang memiliki gangguan autisme memerlukan pengetahuan yang luas tentang autisme itu sendiri, sehingga ayah akan memahami arti dari autisme yang sebenarnya. Peneliti melihat tema-tema yang muncul dalam 
penelitian ini dan mencoba untuk mengungkapkan bagaimana proses penerimaan yang dialami setiap partisipan. Tahap-tahap yang terjadi dalam seuatu proses penerimaan adalah tahap denial, tahan anger, tahap bargaining, tahap depression dan hingga pada akhirnya mengalami tahap acceptance (Ross, 2008).

Ketiga partisipan mengalami tahap demi tahap yang dilalui untuk menuju penerimaan (acceptance), namun dari ketiga subyek tidak selalu berurutan tahap yang dialami. Ross (2008) mengatakan tidak selalu individu akan menglami tahap penerimaan secara berutan seperti yang ada dalam teori. Tahap pertama adalah tahap denial, yang pada umumnya partisipan dapat menerima kenyataan atas kondisi anaknya ketika didignosa autisme. Hanya saja dua partisipan merasa bingung, harus bagaimana dengan kondisi tersebut. Partisipan satu sempat merasakan kurang percaya diri memiliki anak autis. Hal tersebut sesuai dengan pendapat Ross (dalam Sarasvati, 2004) yang mengtakan bahwa tidak mudah bagi orangtua manapun untuk dapat menerima apa yang terjadi dengan kondisi anak mereka. Terkadang terlintas perasaan malu mengapa hal tersebut dapat terjadi didalam keluarga mereka. Berbeda dengan apa yang dialami oleh partisipan tiga (Tono), dirinya tidak merasa kebingungan atau gelisah saat pertama kali mengetahui anaknya autis. Tono menyadari bahwa ada keanehan yang terjadi pada anaknya, Tono hanya menduga bila anaknya mengalami keterlambatan dalam berbahasa. Sejak awal Tono sudah merasa bahagia dengan kehadiran anak keduanya tersebut, hal ini yang menjadikan Tono tidak mengalami denial.

Tahap kedua adalah tahap anger, reaksi marah bisa kepada diri sendiri atau kepada pasangan hidup, bisa juga muncul dalam bentuk menolak mengasuh anak (Ross, 2008). Pernyataan yang sering muncul dalam hati seperti "mengapa keluarga kami mengalami ini?". Ketiga partisipan memiliki pemimkiran "mengapa anaknya bisa menjadi autis?". Ketiga partisipa merasa kecewa terhadap diagnosa awal yang tidak tepat dari dokter. Ketiga partisipan mulai muncul kemarahan akibat pandangan negatif dari keluarga beserta orang disekitarnya, partisipan satu (Alex) dirinya sangat marah karena adanya pandangan yang meremehkan dirinya dari keluarga besarnya. Partisipan 2 (Seto) mulai muncul kemarahan saat dirinya menyalahkan istri, seto menyalahkan istrinya karena tidak memberikan ASI secara eksklusif pada anaknya.

Tahap ketiga adalah tahap bargaining (tawar-menawar), pada tahap ini individu akan melakukan tawar-menawar dengan kondisi yang tidak ia inginkan. Ketiga partisipan berusaha untuk memunculkan pemikiran positif dalam diri mereka dimana mereka menganggap memiliki anak autis merupakan suatu pencobaan bagi keluarga mereka. Partisipan 3 sangat yakin dengan apa yang dia percaya bahwa anaknya akan dapat disembuhkan oleh Tuhan, Tuhan tidak mungkin meninggalkan dirinya. Partisipan 2 percaya bahwa bila dirinya dan istrinya terus berusaha mencari penanganan alternatif, maka anak mereka akan sembuh. Partisipan 1 mulai bargaining saat dirinya merasa bahwa dirinya harus bangkit untuk mengatasi masalah yang terjadi, partisipan 1 mencoba untuk membuktikan kepada keluarganya bahwa dirinya mampu mengatasi masalah autisme pada anak dan langkah yang dipilih partisipan 1 adalah dengan menempatkan anak kepada rumah terapi autisme.

Tahap keempat adalah tahap depression (depresi), tahap dimana seseorang mulai merasa depresi dengan kondisi yang dihadapi. Partisipan 1 sempat merasakan bahwa dirinya putus asa dalam menghadapi pandangan negatif dari pihak keluarga besarnya. Partisipan 2 merasa putus asa dalam upaya menangani anak ditempat terapi dan tempat alternatif lain. Perasaan putus asa merupakan sebagian dari depresi yang muncul saat orang tua 
mulai membayangkan kondisi anak dimasa depan nanti. Berbeda dengan kedua partispan yang lain, partisipan ke 3 tidak merasakan putus asa, bahkah dirinya bersyukur memiliki kondisi buruk tersebut. Perasaan bersyukur partisipan 3 dikarena anggapan yang muncul dalam dirinya bila pencobaan yang sedang ia alami merupakan bukti bahwa Tuhan mencintai dirinya dan keluarga. Partisipan 3 sangat mempercayai bahwa anaknya merupakan titipan yang luar biasa dari Tuhan, dan percaya bahwa dirinya yang mampu mendapat kepercayaan tersebut dari Tuhan.

Tahap terakhir yaitu tahap acceptance, dimana seseorang sudah benar-benar menerima kodisi buruk yang dialami dengan segala kerelaan hati bahwa kondisi yang tidak menyenangkan itu memang menjadi bagian dari pengalaman hidupnya. Ketiga partisipan berada pada tahap ini karena mereka sudah benar-benar mengerti tentang autisme yang dialami anak. Ketiga partisipan menyadari anak penyandang autisme memang membutuhkan kasih sayang. Partisipan 1 yang selalu berkonsultasi dengan guru pendamping anak ditempat terapi untuk terus memantau bagaimana perkembangan anak. Partisipan 2 dan 3 memang sibuk dengan pekerjaan, tetapi bukan berarti mereka tidak mau tahu tentang perkembangan apa saja yang sudah dialami anak. Tahap ini membuat orangtua sudah menyadari kenyataan baik secara emosional maupun intelektual, dengan terus mengupayakan penyembuhan (Ross dalam Sarasvati, 2004). Orangtua dalam tahap ini cenderung mengharapkan yang terbaik sesuai dengan kemampuan anaknya.

Gambaran penerimaan yang muncul dalam sebuah proses penerimaan, selain dapat dilihat dari tahap-tahap penerimaan ketiga partisipan. Gambaran penerimaan ayah terhadap anak autisme dapat melalui bentuk-bentuk penerimaan yang dialami seorang ayah dalam menerima anak autis. Bentuk pertama adalah memahami keadaan anak apa adanya seperti kekurangan pada anak, kelebihan yang dapat dilakukan anak. Partisipan 1 dan 3 memahami bentul mengenai anak, apa saja kekurangan anak dan apa perkembangan positif yang dapat dilakukan anak. Antara partisipan 1 dan 3 yang lebih memahami bentul tentang anak adalah partisipan 1, hal ini diakrenakan partisipan yang menangani dan mengurus semua keperluan anak sehari-hari. Sedangkan partisipan 2 tidak begitu memahami tentang anak, partisipan 2 sangat sedikit sekali memiliki waktu bersama anak.

Bentuk kedua menyadari apa yang bisa dan belum bisa dilakukan anak. Partisipan 1 menyadari apa yang sudah dan yang belum dapat dilakukan oleh anaknya dengan sering berdiskusi dengan terapi (guru pendamping) yang menanngani anaknya. Hal ini seperti pendapat Danuatmaja (2004) yang mengatakan bahwa ketika orangtua sudah mulai jujur dan menceritakan keseharian anak akan membantu terapis dalam mengevaluasi kondisi anak yang dapat mempengaruhi kemajuan perkembangan anak. Penelitian ini menemukan bahwa partisipan 1, partisipan 2 dan 3 memantau kemajuan anak dari berdiskusi dengan istri setiap harinya. Partisipan 2 dan 3 selalu bertanya kepada istrinya bagaimana anaknya disekolah.

Bentuk ketiga adalah membentuk ikatan batin dengan anak. Partisipan 1 membentuk ikatan batin dengan mengajak bermain bersama ketika ada waktu luang serta tidur bersama anak. Partisipan 2 dengan cara mengajak anak jalan-jalan dan memanjakan anak dengan membelikan apa yang diinginkan anak. Partisipan 3 tidak bisa mengajak anak bermain, karena partisipan 3 mengerti bila anaknya tidak dapat diajak untuk bermain bola bersama. Puspita (2004) mengatakan bahwa orangtua harus bersikap hangat setiap kali bersama anak, sikap orangtua yang positif biasanya dapat membuat anak lebih terbuka akan pengarahan dan dapat 
membantu perkembangan anak kearah yang lebih positif.

Bentuk keempat adalah mengupayakan alternatif penanganan lain selain terapi ditempat terapi anak berkebutuhan khusus. Partisipan 1 dan 2 selalu berupaya untuk terus mencara penanganan anak dengan cara tradisional dan religius. Partisipan 1 penanganan yang dilakukan juga melalui obat-obat tradisional guna mengantisipasi bial anak mengalami panas tinggi. Partisipan 3 tetap fokus dengan terapi yang dilakukan anak, dan terus menambah wawasan dengan membaca informasi seputar autisme melalui media elektronik. Danuatmaja (2003) mengatakan bahwa memang orangtua perlu untuk memperkaya pengetahuan mengenai autisme terlebih lagi pengetahuan mengenai terapi yang tepat dan sesuai dengan kebutuhan anak.

Peneliti menemukan beberapa faktor yang mempengaruhi penerimaan ayah terhadap anak autis. Pertama adalah dukungan dari keluarga besar. Partisipan 3 yang benar-benar mendapat dukungan dari keluarga besar dan tidak mempermasalahkan anaknya autis. Partisipan 1 mendapatkan penolakan dari keluarga besarnya yang selalu meremehkan partisipan 1, sedangkan untuk partisipan 2 keluarga besar hanya mempertanyakan dan membanding riwayat kesehat leluhurnya tidak ada yang autis. Sarasvati (2004) mengatakan semakin kuatnya dukungan keluarga besar, orangtua akan terhindar dari merasa "sendirian", sehingga menjadi kuat dalam menghadi cobaan yang dialami karena dapat bersandar pada keluarga besar mereka.

Faktor kedua adalah kepercayaan religius, kepercayaan yang kuat akan Tuhan membuat orangtua merasa yakin mereka mampu mengatasi cobaan dari Tuhan sesuai dengan porsi kemampuan mereka (Sarasvati, 2004). Ketiga partisipan memiliki kepercayaan religius yang tinggi, partisipan 1 dan 2 selalu mencurahkan segala keluh kesah tentang anaknya dalam sholat mereka. Sama halnya dengan partisipan 3 yang sangat mempercayai mujizat dari Tuhan bahwa Tuhan akan mampu menyembuhkan anaknya.

Faktor ketiga yang terlihat dalam penelitian ini adalah tingkat pendidikan ayah. Partisipan 3 memiliki latar belakang pendidikan S1, maka lebih tanggap dalam menangani anak dan bahkan partisipan selalu mengupdate informasi mengenai autis melalui media elektronik HP. Sehingga partisipan tidak pernah merasa depresi dan mampu lebih cepat menerima anaknya dengan segala keterbatasaan yang dimiliki anaknya. Partisipan 2 yang dengan latar belakang SD, ketika mengetahui diagnosa autis pada anak partisipan sama sekali tidak mengerti autisme itu apa.

Ada juga aspek-aspek penerimaan yang muncul dalam proses penerimaan ketiga partisipan penelitian. Aspek-aspek penerimaan orangtua meliputi, menghargai anak sebagai individu dengan segenap perasaan, mengakui hak-hak anak dan memenuhi kebutuhan untuk mengekspresikan perasaan, mencintai anak tanpa syarat, memperlihatkan kecemasan yang minimal dalam kehadiran anak, menerima keterbatasan anak, tidak ada penolakan yang ditampakkan pada anak, dan adanya komunikasi dan kehangatan antara orangtua dan anak (Ninggrum, dalam Laurent, 2011). Aspek menghargai anak sebagai individu dengan segenap perasaan. Ketiga partisipan mengartikan anak mereka adalah anugerah yang sangat istimewah. Partisipan 1 menerima dengan segenap hatinya dirinya bersyukur atas anugerah anak dengan segala keterbatasaan anak dirinya menerima dengan ikhlas. Partisipan 2 memiliki suatu harapan dan doa pada anaknya, anak merupakan anugerah istimewah bagi dirinya. Partisipan 3, anak adalah anugerah dari Tuhan yang luar biasa dalam hidupnya, partisipan 3 percaya bahwa Tuhan mempercayakan anak autis kepadanya berarti dirinya mampu untuk merawat dengan baik. Aspek kedua mengakui hak- 
hak anak dan memenuhi kebutuhan untuk mengeksprsikan perasaan. Partisipan 1 memenuhi kebutuhan anak dengan menyediakan segala keperluan anak sehari-hari dan merawat anak sepenuhnya dirumah maupun disekolah. Partisipan 2 dan 3 lebih cenderung memenuhi kebutuha secara finansial, dimana partisipan mau bekerja kerja demi biaya untuk menerapi anak. Partisipan 3 dengan sadar mengakui hak anak, dengan memposisikan orangtua merupakan kunci utama dalam perkembangan anak.

Aspek ketiga yaitu mencintai anak tanpa syarat. Ketiga partisipan mencintai anak mereka tanpa adanya keterpaksaan dari pihak manapun. Hal ini dibuktikan dengan pernyataan partisipan 3 yang mengatakan apapun kondisi anaknya dirinya akan tetap menyayanginya. Partisipan 1 menunjukan perasaan cintanya kepada anak dengan menjadi pengasuh keseharian anak, mulai dari menyuapi anak hingga memandikan anak. Sedangkan partisipan 2 tidak menunjukan dengan sikap, melainkan dengan perhatian yang selalu menanyakan kondisi anak kepada istri melalui alat komunikasi. Aspek memperlihatkan kecemasan yang minimal dalam kehadiran anak. Partisipan 2 masih merasakan kecemasan akan masa depan anak, cemas bila dirinya dan istri suatu ketika tidak ada untuk mendampingi anak. Aspek berikutnya menerima keterbatasaan anak, ketiga partisipan dapat menerima segala keterbatasaan anak. Partisipan 1 menerima dengan tulus membantu anak, seperti dalam hal mandi secara mandiri dan makan. Partisipan 2 menyadari keterbatasaan anak sehingga tidak memiliki harapan yang terlalu tinggi untuk menempatkan anak disekolah formal. Sedangkan partisipan 3 menerima dan mengakui bahwa anaknya sangat lemah dalam hal bersosialisasi, oleh sebab itu terkadang partisipan 3 merasa bersalah.
Aspek tidak ada penolakan yang ditampakan pada anak. Ketiga perilaku partisipan tidak ada yang menolak anaknya. Partisipan 1 merasa lelah dalam mengurus anak, tetapi tidak ada sikap yang terlihat bahwa dirinya menolak anak. Partisipan 2 cenderung ingin lebih dekat dengan anak, namun anaknya yang tidak ingin didekat ayah saat dirumah. Perilaku partisipan 3 lebih cenderung sebagai pelindung anak, sehingga tidak ada sikap dari ayah yang menolak kehadiran anak. Aspek berikutnya adalah adanya komunikasi dan kehangatan antara orang tua dan anak. Partisipan 1 lebih dekat dengan anak karena partisipan 1 yang sering berperan mengasuh anak dikesehariannya. Partisipan 2 dan 3 kurang dekat dengan anak, partisipan 2 jarang melakukan komunikasi dengan anak dikarenkan waktu yang ada dirumah sangat terbatas.

\section{Simpulan}

Berdasarkan hasil penelitian dan pembahasan yang telah diungkapkan, maka kesimpulan dari penelitian ini adalah bahwa ketiga partisipan dapat menerima anaknya yang didiagnosa autisme dengan mengalami beberapa tahap penerimaan. Ketiga partisipan memiliki kesamaan mengenai reaksi awal mengetahui hasil diagnosa anak, ketiga partisipa juga mengalami perasaan marah mengenai pandangan negative orang disekitar tentang anaknya. Tidak hanya memiliki kesamaan, ketiga partisipan juga memiliki perbedaan dalam hal dukungan dari keluarga besar partisipan. Pandangan positif dari keluarga dapat membuat ayah lebih percaya diri dalam menghadapi permasalahaan anak. Sebaliknya jika keluarga besar menanggapi negative mengenai kondisi anak, maka ayah akan cenderung merasa putus asa dan lebih mebanding-bandingkan dengan keluarga lain. 


\section{Daftar Pustaka}

Danuatmaja, B. (2003). Terapi autis dirumah. Jakarta : Puspa Swara.

Delphie, B. (2004). Pembelajaran Anak Tunagrahita. Bandung. PT Refika Aditama.

Greenspan, S. I \& Wieder, S. (2006). The Child with Special Need Mendorong Pertumbuhan Intelektual dan Emosional. Jakarta: Kanoman.

Herdiansyah, H. (2010). Metodologi Penelitian Kualitatif untuk Ilmu-Ilmu Sosial. Jakarta : Salemba Humanika.

Laurent, J. (2011). Penerimaan Orang Tua Terhadap Anak Penderita Psoriasis. Jurnal Psikologi. Depok : Fakultas Psikologi Universitas Gunadarma.

Indra, D. P. (2011). Proses Permaafan Diri Pada Orang Tua Anak Penyandang Autisme. Skripsi. Semarang : Fakultas Psikologi Universitas Katolik Soegijapranata.

Mangunsong, F. (1998). Psikologi dan Pendidikan Anak Luar Biasa. Jakarta : Lembaga Pengembangan Sarana Pengukuran dan Pendidikan Psikologi (LPSP3) UI.
Meodus, P. (2006). Menjadi Ayah yang Efektif. Alih Bahasa : Funky R. Timur. London : Dolphin Book.

Poerwandari. K. E. (2011). Pendekatan Kualitatif Untuk Penelitian Perilaku Manusia. Jakarta:Lembaga Pengembangan Sarana Pengukuran dan Pendidikan Psikologi (LPSP3) Fakultas Psikologi Universitas Indonesia.

Rachmayanti, S. \& Anita Z. (2007). Penerimaan Diri Orang Tua Terhadap Anak Autis dan Perannya dalam Terapi Autis. Jurnal Psikologi, 1 (1),7-17.

Ross, E. K. (2008). On Death and Dying : What The Dying Have to Teach Doctors, Nurses, Clergy and Their Own Families. London and New York: Taylor \& France Group.

Safaria, T., (2005). Autisme : Pemahaman Baru untuk Hidup Bermakna bagi Orang Tua. Yogyakarta : Penerbit Graha Ilmu.

Syarifah, F. (2014, April). Jumlah Anak Autis Semakin Banyak. Diakses pada 25 pebruari 2015 dari: http://health.liputan6.com/read/2031 441/jumlah-anak-autis-semakinbanyak. 